\title{
MICROBIAL FUEL CELL WITH CU-B CATHODE POWERING WITH WASTEWATER FROM YEAST PRODUCTION
}

\author{
Barbara Włodarczyk' ${ }^{1}$, Paweł P. Włodarczyk ${ }^{1}$ \\ 1 University of Opole, Faculty of Natural Sciences and Technology, Department of Process Engineering, Dmowskie- \\ go St. 7-9, 45-365 Opole, Poland, e-mail: barbara.wlodarczyk@uni.opole.pl, pawel.wlodarczyk@uni.opole.pl
}

Received: 2017.05.01 Accepted: 2017.05.31 Published: 2017.07.01

\begin{abstract}
With the increasing standard of living, energy consumption increases as well. So, waste production, including wastewater, increases as well. One of the types of wastewater is wastewater from yeast industry. Wastewater from this industry has not only a high pollutants load but it is produced in great amounts as well. Technical devices that can accomplish the wastewater treatment and electricity production from wastewater is a microbial fuel cell. In microbial fuel cells activated sludge bacteria can be used for electricity production during wastewater treatment. The possibility of using the $\mathrm{Cu}-\mathrm{B}$ alloy as cathode catalyst for microbial fuel cells to wastewater treatment of wastewater from yeast industry is presented in this paper. The reduction time for COD with the use of microbial fuel cell with the $\mathrm{Cu}-\mathrm{B}$ catalyst (with 5, 10 and 15\% amount of $\mathrm{B})$ is similar to the reduction time with aeration. The obtained power $(4.1 \mathrm{~mW})$ and the amount of energy $(0.93 \mathrm{Wh})$ are low. But, if one can accept a longer COD reduction time, the obtained amount of energy will allow elimination of the energy needed for reactor aeration.
\end{abstract}

Keywords: microbial fuel cell, cathode, wastewater treatment, yeast industry, renewable energy sources, environment engineering

\section{INTRODUCTION}

Food industry is the driving force for the world economy. It is also the driving force of Polish economy. Unfortunately, the essential feature of food industry is a large amount of wastewater. An example of such wastewater is wastewater from yeast industry. Wastewater from the yeast industry has not only a high pollutants load but it is produced in great amounts as well. The main technology components of polluting effluents are: nitrogen, potassium, total suspension, COD and BOD. Such wastewater is mainly supplied to the agricultural fields (AF) [Kutera 1986]. Those fields utilize the wastewater in the plant-soil environment [Brendecke at al. 1993, Kobya and Delipinar 2008, Thornton 2001, Zub at al. 2008]. For wastewater treatment are used also another methods [Nowak at al. 2013, Płuciennik-Koropczuk at al. 2013]. Most of them are suitable for transformation into raw materials for other technologies.
This way we can reduce their negative impact on the environment and use them as a new source of raw materials. However, part of wastewater from yeast industry is sent to the treatment plant. These wastewater can be used to electricity production before final cleaning in treatment plant. Technical device that can accomplish this task is a microbial fuel cell (MFC) [Logan 2008]. Moreover, MFCs allow simultaneously wastewater treatment. In MFC activated sludge bacteria can be used for electricity production during wastewater treatment [Rabaey and Verstraete 2005, Logan at al. 2006]. The concept of MFC was created the 1960's [Davis and Yarbrough 1962, Logan 2008]. Bacteria that were identified as capable of creating electricity in fuel cells include a wealth of genera of bacteria e.g. Geobacter, Shewanella or Pseudomonas [Bond and Lovley 2003, Chaudhuri and Lovley 2003, Kim at al. 2002, Park at al. 2001, Pham at al. 2003]. So, activated sludge is capable of producing electrons $\mathrm{e}^{-}$and $\mathrm{H}^{+}$jones. 
MFCs are bio-electrochemical systems that are devices that use bacteria as catalysts to oxidize organic and inorganic matter and generate current [Berk and Canfield 1964, Logan 2008]. Industrial wastewater (so, also from the yeast industry) is well suited for use in MFC [Angenent at al. 2004, Verstraete at al. 2005].

In MFC a catalyst of anode are microbes. So, it is important to find a catalyst for cathode. In MFCs carbon is most often used as the cathode catalyst. It is also possible to use metal catalysts for cathode of MFCs [Dumas at al. 2006, Martin at al. 2011]. Theoretical current density is described by the Butler-Volmer exponential function [Bockris and Reddy 2000]. Unfortunately, in real conditions the choice of catalyst is mainly carried out by experimental methods [Bockris and Reddy 2000, Twigg 1989]. For this reason experimental researches of search a new catalysts for MFCs are still conducted [Cheng at al. 2006, Dumas at al. 2006, Logan at al. 2006, Martin at al. 2011, Włodarczyk and Włodarczyk 2015a, Włodarczyk and Włodarczyk 2015b, Włodarczyk and Włodarczyk 2015c, Włodarczyk and Włodarczyk 2016a, Włodarczyk and Włodarczyk 2016b, Włodarczyk and Włodarczyk 2016c, Włodarczyk and Włodarczyk 2016d, Włodarczyk and Włodarczyk 2016e, Włodarczyk and Włodarczyk 2017]. The authors have attempted to demonstrate the possibilities of wastewater from yeast industry treatment using the $\mathrm{Cu}-\mathrm{B}$ alloy as cathode catalyst for MFC.

\section{MATERIAL AND METHODS}

The wastewater from yeast factory (Lesaffre Polska S.A.) was used in measurements. The main stream is directed to agricultural fields as fertilizer, but part of this wastewater is directed to biological treatment plant. The wastewater from factory's biological treatment plant was used in measurements.

The alloys were deposited from a mixture mainly of $\mathrm{NaBH}_{4}(0.02 \mathrm{~mol} / \mathrm{l}), \mathrm{CuSO}_{4} \cdot 7 \mathrm{H}_{2} \mathrm{O}(0.05$ $\mathrm{mol} / \mathrm{l}), \mathrm{NaOH}(1.00 \mathrm{~mol} / \mathrm{l})$ and Trilon $\mathrm{B}(0.12$ mol/l) [Włodarczyk and Włodarczyk 2016f]. The alloys were obtained at temperature $365 \mathrm{~K}$. $\mathrm{Cu}-\mathrm{B}$ alloy was obtained by the method of electrochemical deposition. The alloy was deposited on mesh copper. Before the deposition of the alloy, mesh copper electrode was degreased in $25 \%$ aqueous solution of $\mathrm{KOH}$ (after degreas- ing, the surface shall be completely wettable with water), digested in acetic acid and washed with alcohol [Włodarczyk and Włodarczyk 2016a, Włodarczyk and Włodarczyk 2016f]. The deposit was obtained at temperature $293 \mathrm{~K}$, at current density of deposition $i_{d}$ equal to $300 \mathrm{~A} \times \mathrm{m}^{-2}$. The time of the deposition was 1 hour. The chemical composition of $\mathrm{Cu}-\mathrm{B}$ alloys was determined with the XRD method. The alloy with 5,10 and $15 \%$ of B was selected for measurements.

The measurements of concentration COD changes were a parameter determining the operation of the MFC. The research was conducted in reactors with the capacity of 151 . Measurements of reduction of COD was conducted without aeration, with aeration and with using a MFC [Huggins at al. 2013, Włodarczyk and Włodarczyk 2017]. In the first reactor the wastewater had contact with air only by water mirror. In the second reactor the wastewater was aerated by air pump $(2701 / \mathrm{h})$ and in the third reactor the wastewater was treatment with MFC. The carbon electrode was used as anode and $\mathrm{Cu}-\mathrm{B}$ cathode was in cover. The cover was printed on the $3 \mathrm{D}$ printer (layer thickness was equal $290 \mu \mathrm{m}$ ). The Nafion $117(183 \mu \mathrm{m})$ was used as PEM. The cathode was immersed in aqueous solution of $\mathrm{KOH}$ and was constantly aerated $(151 / \mathrm{h})$. The MFC was loaded with resistance equal $10 \Omega$. The temperature of measurements was equal $293 \mathrm{~K}$. The measurements were carried out to obtain $90 \%$ effectiveness of COD reduction [Huggins at al. 2013]. The initial COD value of the analysed wastewater was $3455 \mathrm{mg} / \mathrm{l}$. During MFC operation, both voltage and current were also measured. Figure 1 shows a scheme of cathode in ABS cover (with $\mathrm{Cu}-\mathrm{B}$ catalyst) and figure 2 shows view of cathode during work. The cathode in ABS cover is in the foreground.

\section{RESULTS}

Figure 3 shows a change of concentration of COD during municipal wastewater treatment without aeration, with aeration and with using a MFC (10\% of B) powering with wastewater from yeast industry

Figure 4 shows a change of concentration of COD during municipal wastewater treatment with using a MFC (with $\mathrm{Cu}-\mathrm{B}$ cathode; 5,10 and $15 \%$ of $\mathrm{B}$ ) powering with wastewater from yeast industry 


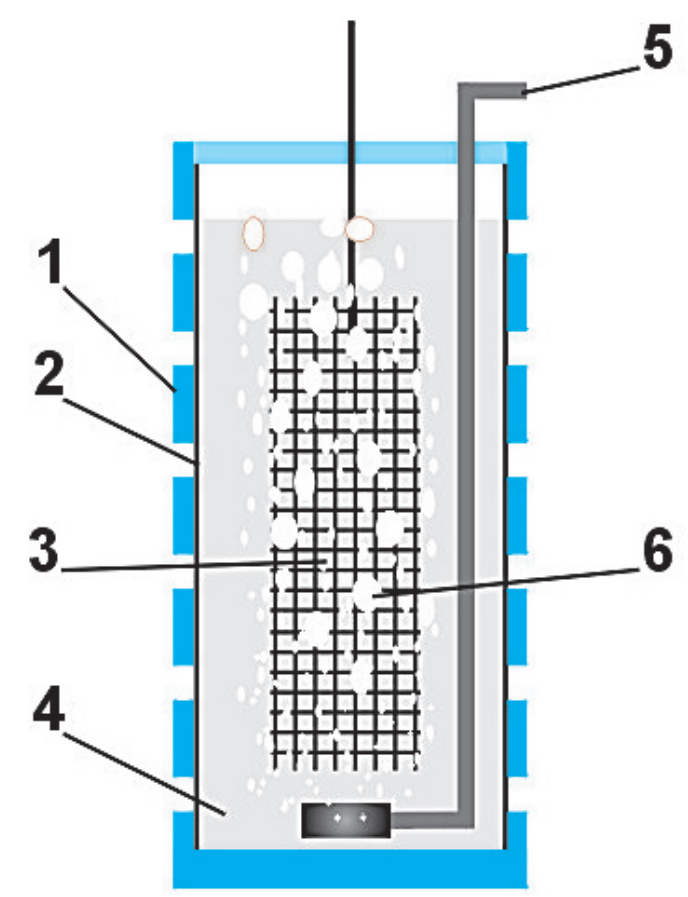

Figure 1. Scheme of cathode

1 - ABS cover, 2 - PEM, 3 - cathode, 4 - aqueous solution of $\mathrm{KOH}, 5$ - air supply, 6 - air bubbles

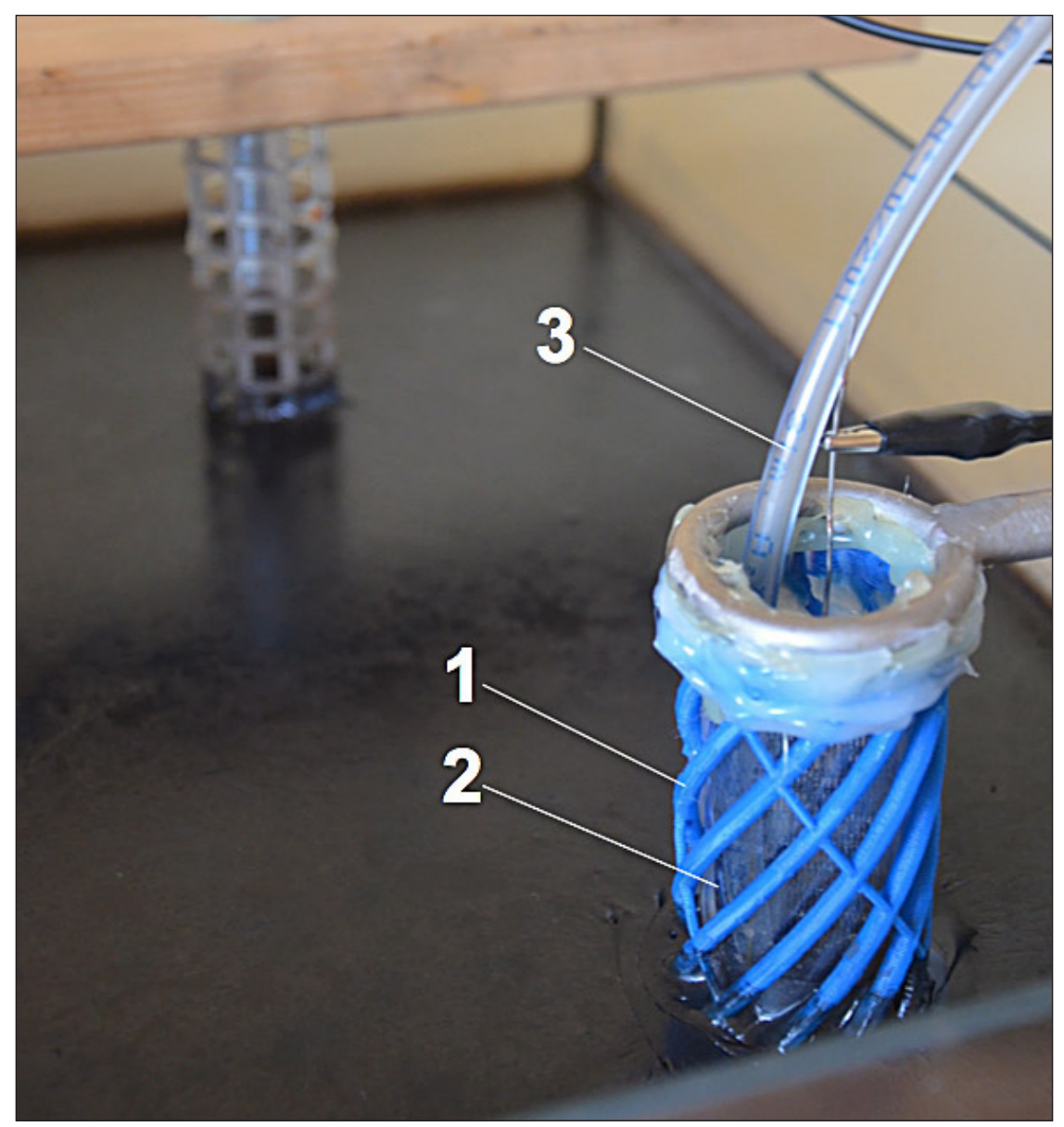

Figure 2. View of cathode during work 1 - ABS cover, 2 - PEM, 3 - air supply 


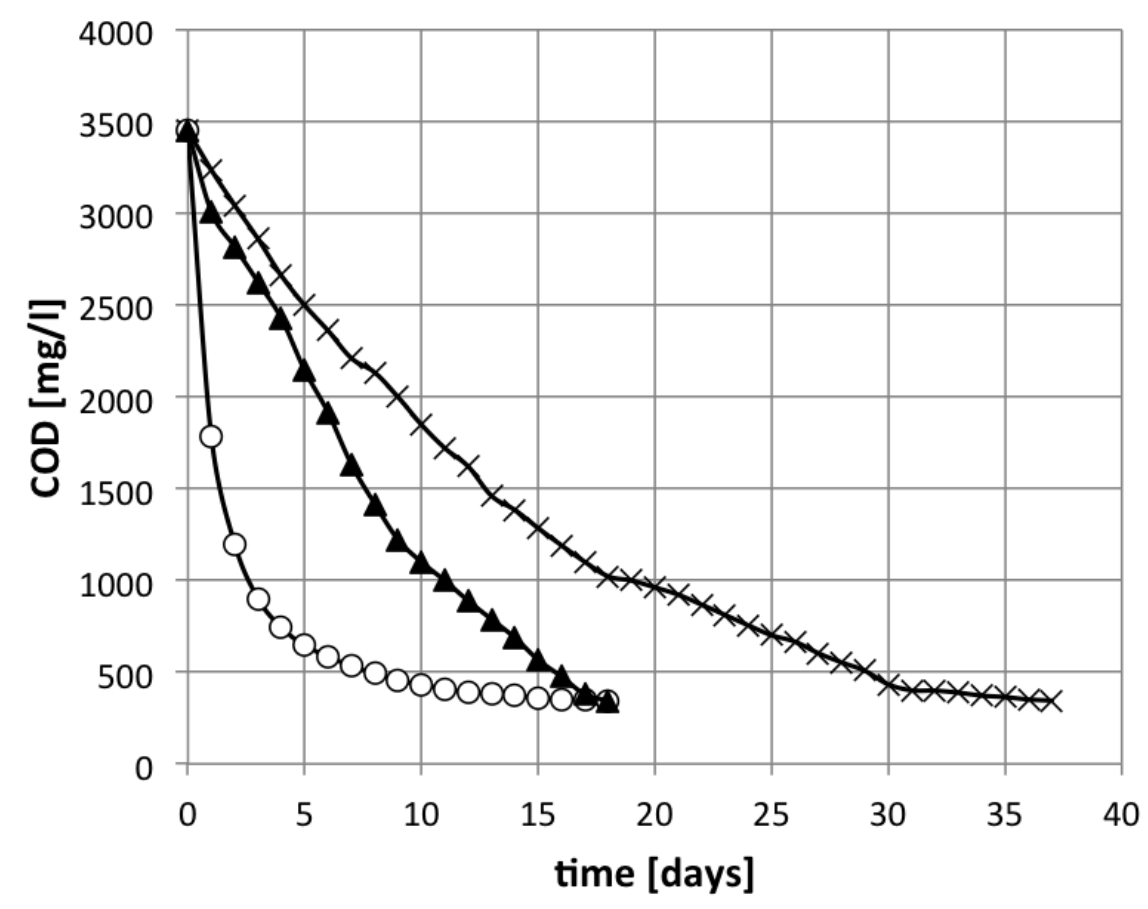

$\rightarrow$ without aeration $\quad \longrightarrow$ - with aeration $\quad \rightarrow$ MFC (10\% B)

Figure 3. Change of concentration of COD during municipal wastewater treatment without aeration, with aeration and with using a MFC (with $\mathrm{Cu}-\mathrm{B}$ cathode) powering with wastewater from yeast industry.

The colours indicate the trend lines of individual data

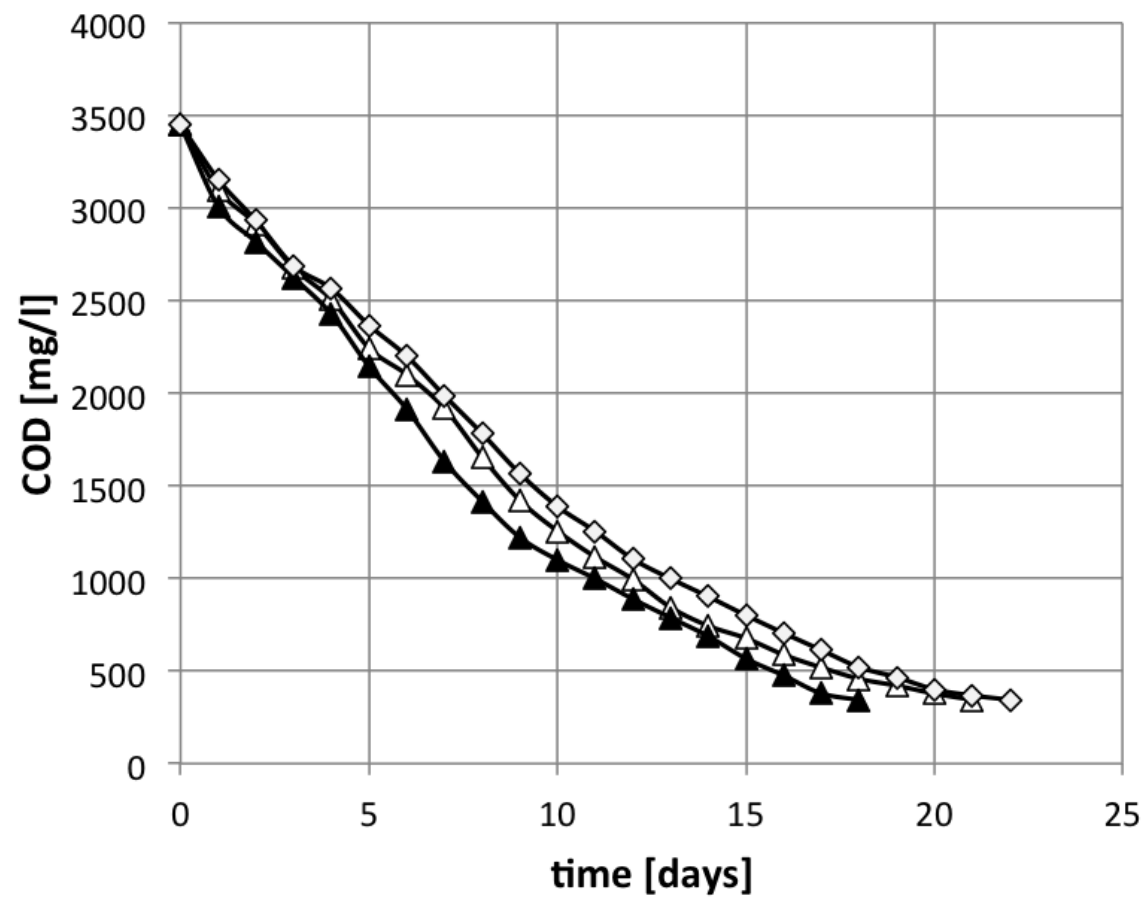

$\neg$ MFC (5\% B) $\leftarrow$ MFC (10\% B) $\prec$ MFC (15\% B)

Figure 4. Change of concentration of COD during municipal wastewater treatment without aeration, with aeration and with using a MFC (with $\mathrm{Cu}-\mathrm{B}$ cathode) powering with wastewater from yeast industry.

The colours indicate the trend lines of individual data 


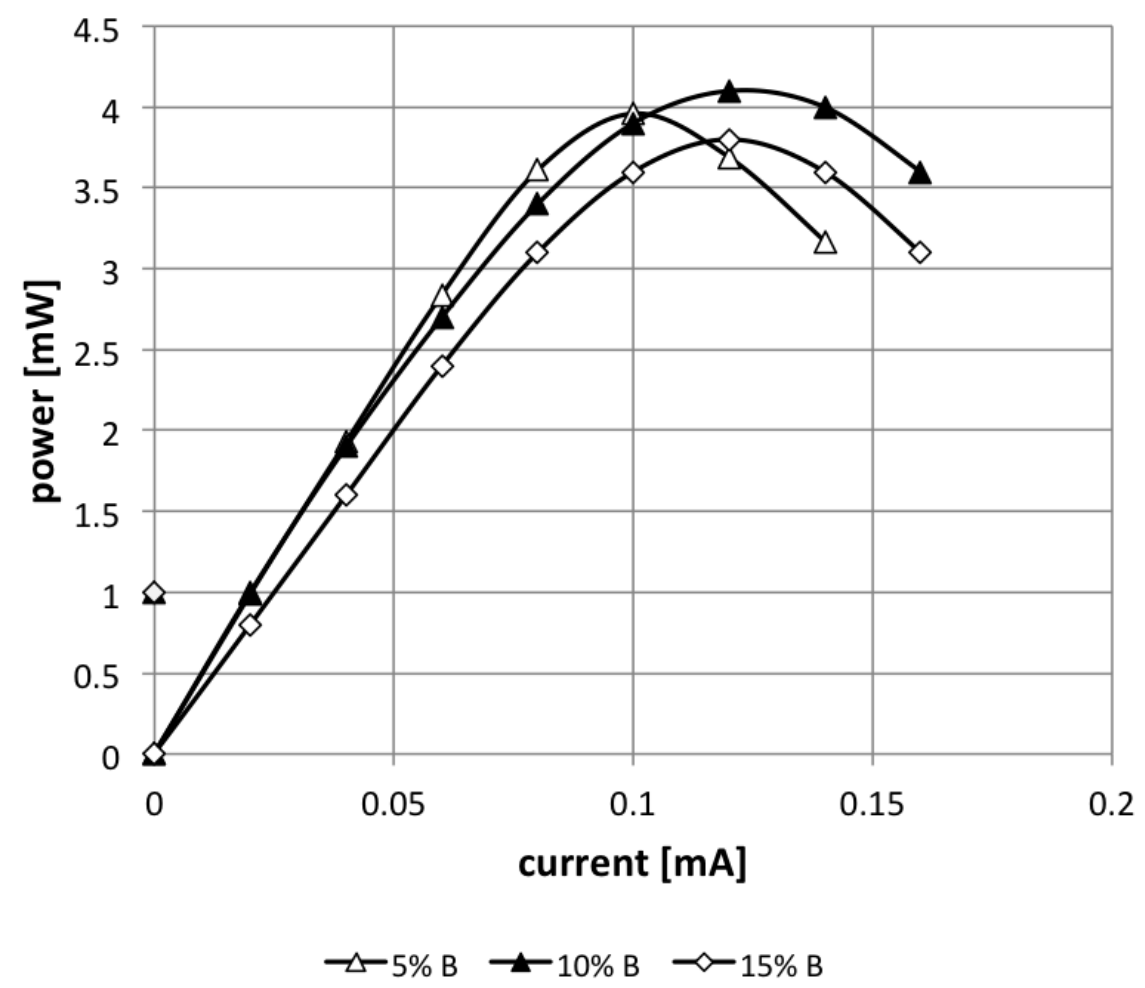

Figure 5. Power curve of MFC (powering with wastewater from yeast industry) with $\mathrm{Cu}-\mathrm{B}$ catalyst $(5,10$, and $15 \%$ of $\mathrm{B})$.

Based on voltage and current the power curve was determined. Figure 5 shows power curve of MFC with Cu-B catalyst $(5,10$, and $15 \%$ of $\mathrm{B})$ powering with wastewater from yeast industry.

\section{CONCLUSIONS}

The measurements show that in any cases (without aeration, with aeration and with MFC) the reduction of COD was $90 \%$. So, measurements have shown the effectiveness of COD reduction in any cases. The time for $90 \%$ effectiveness reduction of COD with the use of MFC (with $\mathrm{Cu}-\mathrm{B}$ cathode) is similar to the reduction time with aeration. But, the characteristics of curves for MFC (with different amount of B) are different in any cases. So, for MFC different amount of $\mathrm{B}$, the time of COD reduction is different. The high effectiveness of COD reduction for $10 \%$ amount of $\mathrm{B}$ was obtained. The characteristic curve of aeration is more preferred than characteristic curve of MFC (with $\mathrm{Cu}-\mathrm{B}$ cathode) because about $80 \%$ effectiveness of COD reduction after about 4.5 days.
Based on voltage and current have been determined current density and power curve. The power obtained during work of MFC with $\mathrm{Cu}-\mathrm{B}$ cathode is equal $3.8-4.1 \mathrm{~mW}$ and average amount of energy for this MFC is equal $0.93 \mathrm{Wh}$. The high power obtained for $\mathrm{Cu}-\mathrm{B}$ catalyst with $10 \%$ amount of B $-4.1 \mathrm{~mW}$. So, the average current density and the amount of energy obtained in MFC are low. But, if one can accept a longer COD reduction time, the obtained amount of energy will allow elimination of the energy needed for reactor aeration. So, a fundamental possibility of using of $\mathrm{Cu}-\mathrm{B}$ alloy as cathode catalyst of MFC for wastewater from yeast industry was obtained in this paper.

\section{Acknowledgements}

This work was created during cooperation between the University of Opole and yeast factory Lesaffre Polska S.A. The project was financed by the European Union from the European Social Fund under the Operational Programme Human Capital 2007-2013. The measurements were conducted during the authors' scientific internship in Lesaffre Polska S.A. 


\section{REFERENCES}

1. Angenent L.T., Karima K., Al-Dahhan M.H., Wrenn B.A., Domíguez-Espinosa R. 2004. The wastewater from yeast factory was used in measurements. Production of bioenergy and biochemicals from industrial and agricultural wastewater. Trends Biotechnol. 22 (9), 477-485.

2. Berk R.S., Canfield J.H., Bioelectrochemical energy conversion. Appl. Microbiol., 12 pp.10-12 (1964).

3. Bockris J.O.M., Reddy A.K.N. 2000. Modern electrochemistry. New York: Kulwer Academic /Plenum Publishers.

4. Bond D.R., Lovley D.R. 2003. Electricity production by Geobacter sulfurreducens attached to electrodes. Appl. Environ. Microbiol., 69, 1548-1555.

5. Brendecke J., Axelson R., Pepper I., 1993. Soil microbial activity as an indicator of soil fertility: Long-term effects of municipal sewage sludge on an arid soil. Soil Biology and Biochemistry, 25 (6), 751-758.

6. Chaudhuri S.K., Lovley D.R. 2003. Electricity generation by direct oxidation of glucose in mediatorless microbial fuel cells. Nat. Biotechnol., 21, 1229-1232.

7. Cheng S., Hong Liu H., Logan B.E. 2006. Power Densities Using Different Cathode Catalysts (Pt and CoTMPP) and Polymer Binders (Nafion and PTFE) in Single Chamber Microbial Fuel Cells. Environ. Sci. Technol., 40(1), 364-369. DOI:10.1021/es0512071

8. Davis J.B., Yarbrough H.F. 1962. Preliminary experiments on a microbial fuel cell. Science, 137, 615-616.

9. Dumas C., Mollica A., Féron D., Basséguy R., Etcheverry L., Bergel A. 2006. Marine microbial fuel cell: Use of stainless steel electrodes as anode and cathode materials. Electrochimica Acta, 53(2), 468-473. DOI:10.1016/j.electacta.2007.06.069

10. Huggins T., Fallgren P.H., Jin S., Ren Z.J., 2013. Energy and performance comparison of microbial fuel cell and conventional aeration treating of wastewater. J. Microb. Biochem. Technol., S6:002. DOI:10.4172/1948-5948.S6-002.

11. Logan, B.E. 2008. Microbial fuel cell. Wiley \& Sons.

12. Logan B.E., Hamelers B., Rozendal R., Schroder U., Keller J., Verstraete W., Rabaey K. 2006. Microbial Fuel Cells: Methodology and Technology. Environ. Sci. Technol., 40(17), 5181-5192. DOI:10.1021/es0605016

13. Kim H.J., Park H.S., Hyun M.S., Chang I.S., Kim M., Kim B.H. 2002. A mediator-less microbial fuel cell using a metal reducing bacterium, Shewanella putrefacians. Enzyme The use of wastewater from spirit and yeast industry in agriculture Microbiol. Technol., 30, 145-152.

14. Kobya M., Delipinar S., 2008. Treatment of the baker's yeast wastewater by electrocoagulation. Journal of Hazardous Materials, 154 (1-3), 1133-1140.

15. Kutera J., 1986. Use of wastewater from spirit and yeast industry in agriculture (in Polish). Falenty. Instructional materials IMUZ (52).

16. Martin E., Tartakovsky B., Oumarou Savadogo O. 2011. Cathode materials evaluation in microbial fuel cells: A comparison of carbon, $\mathrm{Mn}_{2} \mathrm{O}_{3}, \mathrm{Fe}_{2} \mathrm{O}_{3}$ and platinum materials. Electrochimica Acta, 58, 58-66. DOI:10.1016/j.electacta.2011.08.078

17. Nowak A.J., Królik D., Kostecki J., 2013. Wastewater treatment in constructed wetlands. Civil and Environmental Engineering Reports, 11, 93-99.

18. Park H.S., Kim B.H., Kim H.S., Kim H.J., Kim G.T., Kim M., Chang I.S., Park Y.K., Chang H.I. 2001. A novel electrochemically active and Fe(III)reducing bacterium phylogenetically related to Clostridium butyricum isolated from a microbial fuel cell. Anaerobe, 7, 297-306.

19. Pham C.A., Jung S.J., Phung N.T., Lee J., Chang I.S., Kim B.H., Yi H., Chun J. 2003. A novel electrochemically active and Fe(III)-reducing bacterium phylogenetically related to Aeromonas hydrophila, isolated from amicrobial fuel cell. FEMS Microbiol. Lett., 223, 129-134. DOI: 10.1016/ S0378-1097(03)00354-9

20. Płuciennik-Koropczuk E., Sadecka Z., Myszograj S., 2013. COD fractions in raw and mechanically treated wastewater. Civil and Environmental Engineering Reports, 11, 101-113.

21. Rabaey K., Verstraete W. 2005. Microbial fuel cells: novel biotechnology for energy generation. Trends Biotechnol., 23, 291-298.

22. Thornton I. (scienticic co-ordinator), 2001. Pollutants in urban wastewater and sawage sludge. London. Final Report, ICON.

23. Twigg M.V. 1989. Catalyst handbook. London: Wolfe Publishing Ltd.

24. Włodarczyk B, Włodarczyk P.P. 2015a. Comparison of electrooxidation efficiency in microbial fuel cell with a steel catalyst and aeration in wastewater treatment (in Polish). Engineering and Protection of Environment, 18(2), 189-198.

25. Verstraete W., Morgan-Sagastume F., Aiyuk S., Rabaey K., Waweru M., Lissens G. 2005. Anaerobic digestion as a core technology in sustainable management of organic matter. Water Sci Technol. 52(1-2), 59-66.

26. Włodarczyk, P.P. \& Włodarczyk, B. 2015b. Analysis of the possibility of using stainless steel and copper boride alloy as catalyst for microbial fuel cell fuel electrode. Archives of Waste Management 
and Environmental Protection 17(1), 111-118.

27. Włodarczyk B., Włodarczyk P.P. 2015c. Electricity production in microbial fuel cell with $\mathrm{Cu}-\mathrm{B}$ alloy as catalyst of anode. Civil engineering, QUAESTI 2015, 305-308. DOI:10.18638/quaesti.2015.3.1.211

28. Włodarczyk P.P., Włodarczyk B. 2016a. Possibility of wastewater treatment using MFC with NiCo catalyst of fuel electrode, Civil And Environmental Engineering Reports, 21(2), 131-145. DOI: 10.1515/ceer-2016-0028

29. Włodarczyk B., Włodarczyk P.P. 2016b. Microbial fuel cell with $\mathrm{Cu}-\mathrm{B}$ cathode (in Polish), Journal of Civil Engineering, Environment and Architecture, XXXIII, 63(3), 525-532.

30. Włodarczyk B., Włodarczyk P.P. 2016c. Wastewater treatment in microbial fuel cell with Raney-Ni cathode (in Polish). Diagnosing of the Environment Condition, Research Methods - Forecasts, Works of Ecology Commission and Environmental Protection, Scientific Society of Bydgoszcz, 10, 183-192.

31. Włodarczyk B., Włodarczyk P.P. 2016d. Using $\mathrm{NiCo}_{2} \mathrm{O}_{4}$ alloy as cathode catalyst of microbial fuel cell (in Polish). Diagnosing of the Environment Condition, Research Methods - Forecasts, Works of Ecology Commission and Environmental Protection, Scientific Society of Bydgoszcz, 10, 193-203.

32. Włodarczyk B., Włodarczyk P.P. 2016e. Wastewater treatment in microbial fuel cell with $\mathrm{Cu}-\mathrm{B}$ anode (in Polish), Selected issues of environmental protection and renewable energy field, Scientific Publishers TYGIEL, 85-94.

33. Włodarczyk B., Włodarczyk P.P. 2016f. Methanol electrooxidation with $\mathrm{Cu}-\mathrm{B}$ catalyst. Infrastructure and Ecology of Rural Areas, Polish Academy of Sciences Cracow, 4(2), 1483-1492. DOI: http:// dx.medra.org/10.14597/infraeco.2016.4.2.110

34. Włodarczyk B., Włodarczyk P.P. 2017. Use of NiCo alloy as cathode catalyst in single chamber microbial fuel cell (in Polish). Ecological Engineering, 18 (2), 210-216. DOI: 10.12912/23920629/66991

35. Zub S., Kurissoo T., MenertA., Blonskaja V., 2008. Combined biological treatment of high-sulphate wastewater from yeast production. Water and Environment Journal, 22(4), 274-286. 